\title{
Research on Issues of Budget Performance Management on the Process of Budgeting by Game Theory
}

\author{
Zhenchuan Jiang1, Xun Gong2,3* \\ ${ }^{1}$ Graduate School of Lyceum of the Philippines University, Manila, Philippines \\ ${ }^{2}$ School of Economics and Management, Beijing Jiaotong University, Beijing, China \\ ${ }^{3}$ Beijing Center for Industrial Security and Development Research, Beijing, China \\ Email: Jiangzc0810@163.com, *gongxun83@aliyun.com
}

How to cite this paper: Jiang, Z. C., \& Gong, X. (2019). Research on Issues of Budget Performance Management on the Process of Budgeting by Game Theory. Journal of Financial Risk Management, 8, 193-199.

https://doi.org/10.4236/jfrm.2019.84013

Received: September 15, 2019

Accepted: November 17, 2019

Published: November 20, 2019

Copyright $\odot 2019$ by author(s) and Scientific Research Publishing Inc. This work is licensed under the Creative Commons Attribution International License (CC BY 4.0).

http://creativecommons.org/licenses/by/4.0/

\begin{abstract}
Since the remarkable development of economy, the importance of performance has been paid increasing attention to. As an extreme sector of fiscal and tax system, performance of budget is significant to government business and public service. However, some issues of budget performance management are expected to be updated. This paper will analyze the issues on the process of budgeting by game theory.
\end{abstract}

\section{Keywords}

Budgeting, Performance, Budget Performance Management, Fiscal Management Organization, Budget Unit, Game Theory

\section{Introduction}

Recently, in China, with the remarkable development of economy and optimizing of industrial structure, establishing a modern, effective fiscal and tax system is increasingly important. As an extreme sector of fiscal and tax system, budget performance management has been paid increasing attention to. However, some issues are expected to be updated. Finance Bureau at all levels are responsible for budget planning, which plays a decisive role in budget performance management. Improving efficiency, scientific management and serving citizens better are crucial responsibilities for Finance Bureau and target for budget performance management. This paper will analyze the process of budget planning by game theory to response to the issues of budget performance management. 


\section{Literature Review}

\subsection{Related Background}

Fiscal expenditure is the financial funds for the government to provide public facilities and services to satisfy the common needs of the society. Due to functional subjects, fiscal expenditure can be divided into general public service, public security, education, science and technology, culture, health care, environmental protection, agriculture, transportation and so on. Fiscal expenditure can be classified into personnel defray, public defray, to individual and family service, special defray (Boland \& Fowler, 2000). Since the rapid development of market economy, performance has been increasing important in each industry and department. Fiscal performance, especially budget performance is so a key subject to provide better service to citizens and public, that reform in fiscal system has been concluded in three characteristics. Firstly, from focusing on the reform of fiscal revenue to promoting the reform of fiscal expenditure; secondly, from emphasizing the standardization of fiscal expenditure to emphasizing the efficiency of fiscal expenditure; thirdly, from the establishment of financial system to improve the management system and the internal mechanism (Wang, 2014). From the perspective of market economy, it can be concluded that the core task of financial expenditure performance evaluation is to carry out internal control on the government's behavior, so as to ensure the realization of the government's goals and continuously improve the government's operating efficiency (Jia \& Bai, 2005).

\subsection{Budget Performance Management in China and the Issues}

Budget performance is as a result of budget arrangements and implementation, which reflects the outputs of budgets. Based on " $3 E$ ", economy, efficiency, and effectiveness, equity has been involved in budget performance (Wang, 2014). It focuses on whether the citizens, especially vulnerable groups can get fair treatment and enjoy public services, to pay attention to sociality and public satisfaction, and pursue social equity.

The fiscal budget performance management is a significant sector of fiscal system, which can be concluded that it integrates the concept of performance into the existing budget preparation, implementation and supervision, and realizes the organic combination of performance management and budget management (Zamfir, Monica, \& Cristian, 2019). Fiscal budget performance management strengthens the concept of public services and emphasizes the responsibility and efficiency of the budget expenditures. It demands that in the whole process of planning, implementation, supervision, more attention should be paid to the output of the budget. It requires the government to continuously improve the service level and quality, spend less but provide more and better public service (Ministry of Finance, 2011).

However, there are some issues of budget performance need to be updated as soon as possible. At first, the professional skills of financial budget management 
staff are not enough. Budget management is necessary to use people, so the professional level of relevant employees is very important, which can directly affect whether the overall budget management work can be carried out smoothly. If the professional level of the budget management staff is not high enough, the budget management work will be difficult to be finished effectively. It will inevitably affect the performance of budget management (Jia \& Zhao, 2008). Secondly, the informatization level needs to be updated. The development of information technology can bring greater convenience to budget management and save costs. However, the application of information technology of budget management is still not enough. There are two main reasons for this situation: first, related talents are scarce, professional information-based human resources are relatively embarrassing. The employees have both financial and informatization more difficult to employ. Second, the investment of budget management needs to be updated, which makes difficult to achieve effective budget management of informatization. In addition, a more complete institutional system such as assessment system ought to be more effective. The operating funds of the budget are major funded by the state or local finances, which make many departments have no understanding of the performance budget management. The involved people may be misunderstanding of budget performance management and be lack of risk awareness (Zhang, 2007).

\subsection{The Significance of Effective Budget Performance Management}

In order to better develop fiscal function, to accelerate the establishment of a modern fiscal system, to establish an effective budget system, it is necessary to complete budget performance management. The budget performance management is beneficial to strengthen performance management, and develop fiscal expenditure performance and management (Xie, 2012). It means that it helps to further develop the department's sense of public service, promote budget openness. In addition, it plays a positive guiding role in improving financial transparency, and is and an important measure to promote public financial management (Wang, 2014).

Furthermore, budget performance management is positive to construct an expenditure-results-oriented public service system, and improve the content of public finance system (Kelly \& William, 2010). The essential requirement of public finance system is to realize the efficient and scientific use of public resources through the public and democratic reform of finance, so as to continuously improve the public welfare level of the whole society (Sun, 2009).

Nevertheless, budget performance management is conducive to satisfy the needs of the financial development situation and promoting the sustainable development of finance system. An effective budget performance management is necessary to accommodate the growing size of the budget. The related departments need to further strengthen financial management in terms of mechanism concept and methods, constantly improve the efficiency of fund use (Yang, 2019). 


\section{Objective and Methodology}

As mentioned in former sector, budget performance management has some problem in the process of reform of fiscal system. This paper will focus on the initial process of budgeting, and use game theory to analyze possible action of budgeting unit.

As a research method to analyze the distribution of interests, game theory has been paid more and more attention and recognized in many fields of economic and social development (Zhu, 2019). The game theory is mainly used for strategy analysis, which are characterized by participants who may threaten each other or be win-win. Participants make decisions in uncertain situations, and ultimately gain some benefits or may suffer some losses (Alexa \& Toma, 2012). As a mathematical tool for decision makers, the importance of game theory depends on its approach to designing and analyzing strategic decision problems (John, 1994).

\subsection{Games between Fiscal Management Organization and Budget Units}

In this part, it is hypothesized that there are only two main bodies, the fiscal management organization (Department of Financial) and the budget unit (functional departments), and there is no collusion between the two parties. The two parties act in order and the later one can know the former action, so it is a static and asymmetric game with incomplete information. It is widely believed that the fiscal management organization has two kinds of strategies, approve or cut down. The budget unit also has two kinds of actions, inflated report which means to make it possible to gain more budgets; and real report which means to has possibilities to gain less budgets. Therefore, the payoff of the fiscal management organization and the budget unit can be shown in Table 1 .

According to the payoff matrix, there are 4 results. From the perspective of budget units if real budget report is cut down, they will not have enough capital for service and operation. Therefore, they may have more possibilities to inflate budget, the possible strategies for budget units are $[x, y]$ and $[x,(1-y)]$. Because budget units are almost impossible to accept $[(1-x),(1-y)]$, and less possible to put willing in $[(1-x), y]$, a limited possible result.

From the perspective of fiscal management organization, it has responsibility to approve real budget and cut down inflated budget. Because of the lack of professional staff and technology support, it is difficult for fiscal management organization to understand budget in each unit, which means that it costs a great amount of human resource, time and capital to research in each budget unit.

Table 1. Game between two parties (Jiang, 2016).

\begin{tabular}{ccc}
\hline Budget unit management & Approve $(y)$ & Cut down $(1-y)$ \\
\hline Inflated $(x)$ & $x, y$ & $x,(1-y)$ \\
Real $(1-x)$ & $(1-x), y$ & $(1-x),(1-y)$ \\
\hline
\end{tabular}


The higher cost of actions may decrease the possibility of actions. In fact, budget is easily influenced by subjective factors to lead an ineffective result. It can be concluded that it is difficult to gain the best payoff.

Therefore, evaluating the authenticity of budget is serious problem of budget performance management.

\subsection{New Game Involved by Effective Administrative Supervision}

In addition, effective supervision and assessment are regarded as a positive method to solve this problem. Therefore, a new variable is involved in this part, administrative supervision. The author hypothesizes that the new variable has positive effects on budgeting. As mentioned in former part, action of fiscal management organization can be influenced by research cost and subjectivities. Based on model 1, effective budget can be regarded as approving real budget and cutting down inflated budget, the others are ineffective strategies. The new variable may affect the game strategy. Fiscal management would be evaluated by supervision and assessment due to budget strategy.

According to Table 2, fiscal management expects to be rewarded, ineffective budget is difficult to be rewarded. Therefore, fiscal management organization has more willing to approve real budget and cut down inflated budget. Administrative supervision may decrease some subjective factors, because fiscal management organization has less possibilities to be punished by inflated budget report and has more willing to cut down budgets. As a result, the possibility to cut down real budget would increase. Thus, this situation may decrease the possibility of effective budgets because the high cost and lack of professional supports of fiscal management organization are still existing. In this game, the involved supervision and assessment hardly help increase the possibility of effective budgeting.

Therefore, it can be deduced that the core issue of budgeting is the cost of research in budget unit and evaluate the possibility of real budget report.

\section{Conclusion and Recommendation}

It is widely believed that budgeting is the base of budget performance management, an effective budget plan is important to the fiscal system. Refer to the game model, the best payoff is fiscal management organization that approves a real budget. However, it is difficult to gain the most effective budget because of high research cost. In addition, administrative supervision is difficult to solve the issue perfectly.

Table 2. New game (Jiang, 2016).

\begin{tabular}{ccc}
\hline & \multicolumn{2}{c}{ Supervision and assessment } \\
\hline Fiscal management & Reward $(Z)$ & Punish $(1-Z)$ \\
\hline Effective budget & {$[(1-x) y+x(1-y)], Z$} & {$[(1-x) y+x(1-y)],(1-Z)$} \\
Ineffective budget & {$[x y+(1-x),(1-y)], Z$} & {$[x y+(1-x),(1-y)],(1-Z)$} \\
\hline
\end{tabular}


Therefore, in order to make budget performance more effective, it is important to improve the abilities of budgeting employees, training management staff to understand the business of budget unit. Enough abilities and comprehension of business are positive for management organization to enhance effectivities.

In addition, utilizing informatization technology may be beneficial to decrease cost of budget. Big data can reduce some human resource and time cost which is an effective method to enhance budget performance management efficiency.

\section{Conflicts of Interest}

The authors declare no conflicts of interest regarding the publication of this paper.

\section{References}

Alexa, V., \& Toma, S. (2012). The Correlation between Game Theory and International Trade. Economics and Applied Informatics, 18, 67-74.

Boland, T., \& Fowler, A. (2000). A System Perspective of Performance Management in Public Sector Organizations. International Journal of Public Sector Management, 13, 417-446. https://doi.org/10.1108/09513550010350832

Jia, K., \& Bai, J. M. (2005). Key Points of Performance Budget and Government Performance Evaluation. (In Chinese) http://www.docin.com/p-266499922.html

Jia, K., \& Zhao, H. Q. (2008) Review and Prospect of China's Fiscal and Tax Reform in the Past 30 Years. (In Chinese)

Jiang, Y. H. (2016). The Mechanism Study of Financial Supervision Embedded into Budget Management Based on Game Theory. University of Human. https://www.ceeol.com/search/article-detail?id=779234

John, M. (1994). Game Theory in International Economics. Langhorne, Pennsylvania, PA: Harwood Academic Publishers.

Kelly, J., M., \& William, C. R. (2010). Performance Budgeting for State and Local Government. Portland: M.E. Sharpe, Inc.

Ministry of Finance (2011). Guidance on Promoting Budget Performance Management No. 416. (In Chinese) http://www.gov.cn/gzdt/2011-07/27/content_1915094.htm

Sun, K. J. (2009). Game Analysis of Department Budget Performance Management. Journal of Nanjing University of Finance and Economics, No. 156, 52-55. (In Chinese)

Wang, H. T. (2014). The Research on Budget Performance Management's Reform in China. Research Institute for Fiscal Science, Ministry of Finance. (In Chinese)

Xie, X. R. (2012). Financial Management and Public Service-Achievements in Fiscal Development and Reform Since the 16th CPC National Congress (2002-2012). Beijing: People's Publishing House. (In Chinese)

Yang, R. H. (2019). Problems and Countermeasures in Budget Performance Management of Administrative Institutions. Accounting learning, No. 22. (In Chinese) http://www.fx361.com/page/2019/0818/5437580.shtml

Zamfir, M., Monica, P., \& Cristian, F. (2019). The Budget-Reference System in Assessing the Performance of the Public Enterprise. Academic Journal of Economic Studies, 5, 144-145. https://www.ceeol.com/search/article-detail?id=779234

Zhang, X. (2007). Public Finance Reform: Enlightenment of New Public Management. 
Public Finance Research, 4, 34. (In Chinese)

Zhu, S. X. (2019). Problems and Countermeasures in Comprehensive Budget Management. Commercial Accounting, 7, 170-171. (In Chinese) 